\title{
THE REGIONAL STRUCTURE OF RETAIL SECTOR IN THE NORTHERN HUNGARY REGION
}

\author{
Gábor Koncz - Konrád Kiss - Dóra Nagyné Demeter
}

\begin{abstract}
The retail sector plays a decisive role in the development of urban-rural relations. As it is not only a narrower segment of the population that participates in it and it is a good measure of the central role of cities on a market basis. Our study is part of a broader research project covering the North Hungarian region, where we investigate market access opportunities for local producers through short supply chains. As a basis for the primary research of a greater project we conducted secondary research based on the databases of the Hungarian Central Statistical Office. In addition to the number of retail stores, we investigated the possible impacts of changes in population and incomes on demand for retail stores and centres in each city and their surrounding rural areas. In terms of the socio-economic sense, the region shows a less favourable picture than the national average, which also manifests itself in the lower number of retail units. However, in the region, significant differences can also be observed in the settlement hierarchy and spatial characteristics. There is some duality in the fact that the population per unit of trade is relatively high, but at the same time, the number of units in the examined chain stores is relatively smaller in the region.
\end{abstract}

Keywords: retail amenities, market sizes, regional competition, settlement structure, spatial concentration

JEL: L81, R12 


\section{Introduction}

Our secondary study was carried out as part of a complex research project to explore the situation and development opportunities of sales forms that meet the expectations of short supply chains (SSCs) (Examination of value-added chains, determination of its representative spatial data in urban-rural relation). In the framework of the project, in addition to a review of the relevant literature, we collected statistical data and conducted primary research among both producers and consumers. The market is basically not dominated by forms of sales that can be categorized into SSC, also called alternative forms of sale, at the same time, the practical benefits of our research may be to help small producers' goods reach markets more efficiently in the future. Different parts of its regions have differentiated geographical features, which has made it an inevitable task for us to explore the current spatial structure of retail.

Retail is currently a saturated, concentrated market, regardless of the level of development of the regions. In markets, global supply chains have the largest market shares, and small commercial units can easily be pushed out of markets due to increasing concentration (Tömöri, 2015). Despite the fact that the turnover of traditional stores has not decreased, the number of stores and the share of small shops is expected to decrease further in the future, which, however, will not proportionally reduce the total sale space of the stores (Kozák-Neszmélyi, 2018). Based on past experience, economic crises even reinforce this process (Tömöri, 2014,).

Examination of the spatial position of commercial units, peculiarities of visiting shops is one of the most researched topics in economic geography (Golledge-Stimson, 1997). The range and distribution of retailers has changed dramatically in the last two to three decades, constantly posing new challenges to management of international hypermarkets and supermarkets as well as discount chains (Sikos et al., 2019). The performance of elements in commercial networks is continuously evaluated and their distribution is rationalized (Reynolds-Wood, 2010). In Hungary, too, we can find several examples of companies leaving and liquidating stores and the regional networks of store chains. The population development of an area (market) fundamentally influences the quantitative needs of consumers in the area. The information obtained from loyalty card programs allows retail chains to track the composition of consumption based on other aspects as well. Larger retail chains assess in detail the potential location of stores in the region and in town (Birkin et al., 2017).

The development of the service sector in a given territorial unit is fundamentally influenced by its population, the urban-rural relationship system within the area and the competitive situation between the neighbouring regions. (Burger et al., 2013). Research on retail geography prefers to examine the degree of concentration in key centres of the sector (Wrigley, 2009), while the availability of basic retail units in peripheral areas can be a problem. Urban centres are traditional centres of retail 
activities, but the benefits of favourable transport hubs are also manifested at lower levels of the network hierarchy (Han et al., 2019).

Of course, the choice of location is a strategic decision not only among the store chains, but also among the smaller actors, which in many cases focuses on the position of the store within the settlement or the district. However, they have much less information about potential consumers and competitors. Smaller stores are often the focus of interest because their legitimacy in the market becomes questionable (Kozák, 2014).

In a market with a small population, the presence of advanced producer and business services is not typical. For markets with less than 2000 inhabitants - which can already include several settlements in a small village area - the literature mentions natural markets characterized by low demand and self-service, and the fact that residents visit other settlements to meet their needs (related to purchases and services). It is not uncommon for villages in the peripheral areas of the Northern Hungary region not to have a grocery store in their administrative units (Kápolnai, 2017; Sikos, 2019).

\section{Material and methods}

We carried out our study purposely in the area of the Northern Hungary region. Because this analysis based on secondary data sources is closely related to our research program in the region which examines the role of SSCs. The subject of this is the potential of short supply chains and the factors that influence them. The study area has been the least developed region in Hungary for many years, but since 2012 they have managed to reverse the lagging trend. GDP per capita data increased from $58.9 \%$ to $69 \%$ of the national average in the five years until 2018 . The population that fundamentally influenced the amount of consumption in the region decreased by $5.9 \%$ between 2010 and 2018 . Youth emigration is a striking phenomenon in the region, but the decline in population due to the difference between live births and deaths has been greater in the average for the last 8 years ( -5509 people/year), which was one and a half times the migration loss (-3665 people/year). The demographics of the region are a good reflection of the aging population structure. At the same time, the increase in economic performance has also had a positive effect on incomes, helping some rural areas to catch up. However, this was largely due to commuters who work mainly in industrial centres (Koncz et al. 2018).

For the study, we used data available at the settlement and district level in the databases of the Hungarian Central Statistical Office to present the regional distribution of retail stores in the period between 2010 and 2018. Because the statistics on the number of stores obscure the size and real role of the stores, we collected information from the own webpage of large chain stores to more accurately 
explore the spatial structure of retail. Our analysis was performed for the entire sector of the retail store network. Spatial differences were also illustrated by calculating the Herfindahl-Hirschman index (concentration coefficient).

\section{Results and discussion}

Demographic and income trends, which have a major impact on consumption, have been at odds in recent years. The development of the economy of the Northern Hungary region could be measured not only through the GDP data per capita, but also in the income data, which is much more important information for the population. The value of total domestic income on the per capita PIT tax base in the region increased from $83.9 \%$ of the national average to $87.7 \%$ between 2010 and 2018. Among the counties, Heves county is in the most favourable position in Eastern Hungary, where the income per resident $(96.7 \%)$ is close to the national average. The indicators of Nógrád (85.5\%) and Borsod-Abaúj-Zemplén (84.3\%) counties lag significantly behind it. However, according to the data series, the increase in incomes could not significantly contribute to the increase in the number of commercial units.

In parallel with the declining territorial demand caused by the declining population, the number of commercial units also decreased or even exceeded the rate of population decline. While in 2010 there were still 133 retail stores per ten thousand inhabitants in the region, in 2018 this figure was only 116 . A lower value was observed only in Pest county, a significant part of which is made up of the dormitory towns around Budapest. These are overshadowed by the capital's outstanding strong service sector. Within the country, 9.8\% of retail units will be located within the region in 2018, which is 0.4 percentage points lower than the 2010 regional value.

Among the counties of the Northern Hungary Region, Heves County has the most favourable spatial structure position (M3 motorway, proximity to Budapest) and the least fragmented settlement network (the average population of the settlements was 2435 people in 2018). As a result, the number of retail units per ten thousand inhabitants is also the highest in this county (128), followed by Nógrád County (115), then Borsod-Abaúj-Zemplén County (110) .

The number of retail stores per ten thousand inhabitants was also examined at the district level. In the ranking of 175 districts of the country, the Sátoraljaújhely district occupies the best position with 13th place (the highest value is given to the priority tourist areas next to Lake Balaton). At the same time, six districts in northern Hungary are also among the last ten places in the ranking (Cigánd, Rétság, Edelény, Gönc, Szikszó and Putnok). The regional ranking is led by the districts with a city with a strong secondary central role (above 120). District 
centres with a population of less than 10,000, which are also located in peripheral locations, do not provide a suitable location for diversified retail sector.

At the settlement level, the highest values were achieved by villages with a small population and significant tourism. (e.g. Hollókő, Háromhuta, Aggtelek, Mátraszentimre). Among the cities, they appeared at the top of the list, where the size of the attraction area is relatively large in relation to the population, and even the role of tourism is significant (e.g. Gyöngyös, Eger, Tokaj) (Figure 1).

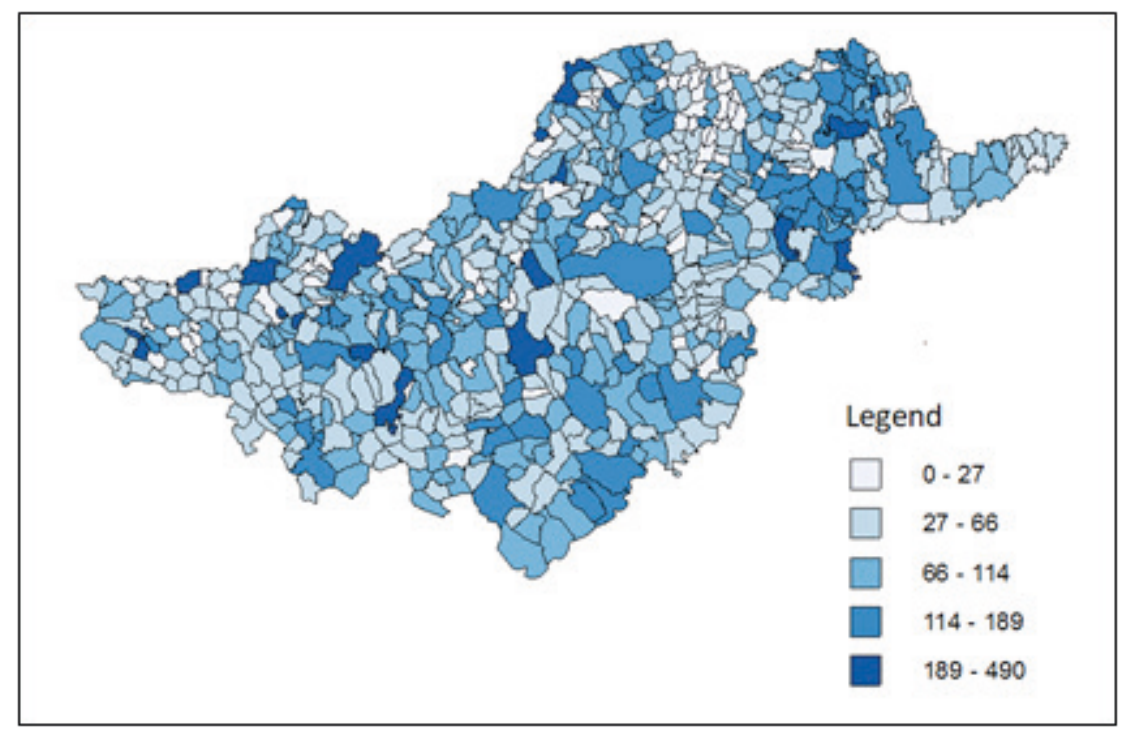

Figure 1: The number of retail stores per ten thousand inhabitants in the settlements of Northern Hungary Source: Hungarian Central Statistical Office (KSH), 2018.

On the thematic map, of course, not only the dominant attraction centres, the major tourist areas and the main spatial structure lines are outlined, but also the settlements and areas that are in short supply in shops. This is most noticeable in peripherally located, small-village, backward areas (e.g. Cserehát), but it can also be observed that medium-sized villages near some cities also have low indicators due to the shading effect of the stronger towns. It should be noted that among the 610 settlements in the region, there are 48 where no retail units operate. This number increased by 10 compared to 2010 , however, the settlements concerned were also replaced partially.

The total number of retail stores and wholesale warehouses in the region decreased from 14,996 to 12,302 between 2010 and $2018.54 .2 \%$ of the latter is located in Borsod-Abaúj-Zemplén County, 28.9\% in Heves and 16.8\% in Nógrád. The store network of Miskolc (the only larger town) within the region (17.2\%) alone exceeds the importance of the whole Nógrád County. The regional centre is followed by the 
only medium-sized town, Eger (8.6\%), then the third county seat, Salgótarján $(5.0 \%)$ and Gyöngyös (4.9\%) - the latter are already considered small-medium towns with a population of 20-50 thousand people. Among cities of similar size, better indicators of more economically prosperous settlements can be clearly observed. A total of 16 cities have a significance above the $1 \%$ threshold within the commercial network, which also include small towns with more favourable conditions (e,g. Balassagyarmat, Mezőkövesd, Tiszaújváros)

There are very few towns in the region where the number of commercial units increased in absolute terms between 2010 and 2018 (such as: Hatvan, Füzesabony, Szécsény, Cigánd). The share of major shopping centres decreased, with Miskolc (-2.4 percentage points) accounting for the largest loss. As a result, the degree of commercial concentration decreased in the region. The value of the concentration index changed from 0.0607 to 0.0516 between 2010 and 2018. The decline was smaller in rural areas, but we cannot state that the supply of the population has improved, with the exception of a few settlements that are developing rapidly and implementing tourism developments.

As we cannot get a really accurate picture of the spatial structure of the region's trade based on the number of commercial units, we prepared a separate report on the members of the larger hypermarkets, supermarkets and chains with discount stores in the region based on an online data collection. Virtually all store chains can be said to have fewer stores in Northern Hungary than the average of rural regions (Table 1). The location of the stores is strongly in line with the specifics of the settlement hierarchy. For example, Tesco stores are present in 12 of the 13 most important shopping centres in the region, with the exception of Sárospatak, which ranks 12th. However, geographically it is located between two other centres, Sátoraljaújhely and Szerencs

Table 1: Investigation of site selection for large shopping malls in the region based on the number of stores (2019)

\begin{tabular}{|l|l|l|l|l|l|l|}
\hline Store chains & \multicolumn{3}{|l|}{$\begin{array}{l}\text { Hyper- and supermarket } \\
\text { profile store chains }\end{array}$} & \multicolumn{3}{l|}{ Discount profile chain stores } \\
\hline Location & $\begin{array}{l}\text { Tesco (hyper } \\
8 \text { super) }\end{array}$ & $\begin{array}{l}\text { Spar \& } \\
\text { Interspar }\end{array}$ & $\begin{array}{l}\text { (CBA) } \\
\text { Príma }\end{array}$ & Lidl & Aldi & Penny \\
\hline $\begin{array}{l}\text { Northern Hungary } \\
\text { Region (pieces) }\end{array}$ & 15 & 29 & 1 & 15 & 6 & 23 \\
\hline $\begin{array}{l}\text { Average of regions } \\
\text { (without Budapest) } \\
\text { (pieces/region) }\end{array}$ & 18,4 & 37,9 & 7,0 & 19,9 & 14,1 & 27,4 \\
\hline $\begin{array}{l}\text { The difference between } \\
\text { Northern Hungary and } \\
\text { the average of regions: }\end{array}$ & $-18.5 \%$ & $-23.5 \%$ & $-85.7 \%$ & $-24.6 \%$ & $-57.4 \%$ & $-16.1 \%$ \\
\hline
\end{tabular}

Source: own collection and editing based on the websites of each store chain (2020). 


\section{Conclusions}

The region of Northern Hungary lags behind the national average based on socioeconomic indicators. This is reflected in the declining trend in both population and store numbers. In terms of the number of stores per ten thousand people, the region only surpasses Pest County (excluding Budapest). This can be largely explained by the peculiarities of the settlement network of the region. There are only one large and one medium-sized city in its city network, along with which some small-medium towns have relatively favourable indicators. The shop network of small towns between 10 and 20 thousand people - especially those with a larger agglomeration - is also still differentiated. However, small towns with less than 10,000 inhabitants no longer have adequate spatial organizing power.

Hypermarkets and supermarkets, as well as discount chains, prefer full-fledged secondary catchment areas, where the exclusion of smaller players from the market is spectacular. The increase in the number of shops has been observed in towns whose economic role and relative spatial position have improved in recent years. In several smaller settlements, the development of tourism generated an increase in the number of shops. On the other hand, in the areas characterized by the worst spatial and settlement structure, the number of settlements is increasing where traditional small shops cannot be maintained, only some alternative form of sales.

In light of our research findings, short supply chains have greater development potential in large cities due to the high number of available consumers. However, it can also play an important role in small settlements where traditional forms of retail slowly disappear.

\section{References}

[1.] Birkin, M. - Clarke G. - Clarke M. (2017): Retail Location Planning in an Era of Multi-Channel Growth. Routledge, London, 258 p. https://doi.org/10.4324/9781315605937

[2.] Bodor N. - Pénzes J. (2012): Eger komplex vonzáskörzetének dinamikai vizsgálata. $=$ Tér és Társadalom 26(3), pp. 30-47. https://doi.org/10.17649/TET.26.3.1929

[3.] Bujdosó, Z. ; Dávid, L. ; Remenyik, B. ; Tóth, G.(2011) Connection between tourism and regional development on the Hungarian-Croatian border Central European Regional Policy and Human Geography 1:2 pp. 27-40. , $14 \mathrm{p}$. 
[4.] Burger, M. J. - Meijers, E. J. - Van Oort, F. G. (2013): Regional Spatial Structure and Retail Amenities in the Netherlands. = Regional Studies 48(12), pp. 1972-1992.

https://doi.org/10.1080/00343404.2013.783693

[5.] Golledge, R. G.-Stimson, R. J. (1997): Spatial Behavior: A Geogrpahic Perspective. The Guilford Press, New York-London, 620 p.

[6.] Han, Z. - Cui, C. - Changhong, M. - Wang, H. - Chen, X. (2019): Identifying Spatial Patterns of Retail Stores in Road Network Structure. = Sustainability 11, 4539, $20 \mathrm{p}$. https://doi.org/10.3390/su11174539

[7.] Kápolnai Zs. (2017): A kiskereskedelem és a szolgáltatások térbeli jellemzői Pest és Nógrád megye aprófalvaiban. $=$ A falu 32(1), pp. 59-68.

[8.] Koncz G.-Szűcs A.-Nagyné Demeter D. (2018): A gazdaság térszerkezetének változásai Észak-Magyarországon az ezredforduló után. = Jelenkori társadalmi és gazdasági folyamatok 13(1-2), pp. 139-149.

https://doi.org/10.14232/jtgf.2018.1-2.139-149

[9.] Kozák T. (2014): Kisboltok vonzáskörzetének meghatározása, azaz dohánybolttelephely kiválasztása kvantitatív módszerekkel. In: Solt, K. (szerk.) Alkalmazott tudományok I. fóruma (konferenciakötet). Budapest, BGF, pp. 476-489.

[10.] Kozák T. - Neszmélyi Gy. I. (2018): Trendek, trendváltások a kereskedelemben. = JURA 24(2), pp. 468-482.

[11.] Reynolds, J.-Wood, S. (2010): Location Decision Making in Retail Firms: Evolution and Challenge. = International Journal of Retail \& Distribution Management 38(11-12), pp. 828-845. https://doi.org/10.1108/09590551011085939

[12.] Sikos T. T. (2019): Komámasszony, hol az üzlet?: Az Abaúji térség élelmiszer üzlethálózatának elemzése. = Észak-magyarországi Stratégiai Füzetek 16(2), pp. 31-38.

[13.] Sikos T. T.-Kozák T.-Kovács A. (2019): New Retail Models in Online and Offline Space. = DETUROPE 11(3), pp. 9-28.

[14.] Tömöri M. (2014): A gazdasági válság hatása a hazai kiskereskedelem térszerkezetére. $=$ Földrajzi Közlemények 138(3), pp. 197-207.

[15.] Tömöri M. (2015): A kiskereskedelem nagy játékosai, avagy transznacionális vállalatok a kiskereskedelemben. $=$ Modern Geográfia 2015/I., pp. 13-29. 
[16.] Wrigley, N. (2009): Retail Geographies. In: Kitchin, R.-Thrift, N. (Eds.): International Encyclopedia of Human Geography. Elsevier Science, pp. 398-405.

https://doi.org/10.1016/B978-0-08-102295-5.10216-1

https://doi.org/10.1016/B978-008044910-4.00226-1

\section{Internet resources:}

[1.] www.aldi.hu (January 2020)

[2.] www.cba.hu (January 2020)

[3.] www.ksh.hu (March 2020)

[4.] www.lidl.hu (January 2020)

[5.] www.penny.hu (January 2020)

[6.] www.spar.hu (January 2020)

[7.] www.tesco.hu (January 2020)

\section{Acknowledgments}

This work was supported by the project entitled: "EFOP-3.6.2-16-2017-00001 Complex rural economic development and sustainability research, development of the service network in the Carpathian Basin." (In original, Hungarian language: "EFOP3.6.2-16-2017-00001 Komplex vidékgazdasági és fenntarthatósági fejlesztések kutatása, szolgáltatási hálózatának kidolgozása a Kárpát-medencében.") 


\section{Authors}

\section{Gábor Koncz (PhD)}

Associate professor

Eszterházy Károly University

Institute of Rural Development and Landscape Management koncz.gabor@uni-eszterhazy.hu

\section{Konrád Kiss}

PhD-student

Szent István University

Doctoral School of Management and Business Administration

konrad.kiss@phd.uni-szie.hu

\section{Dóra Nagyné Demeter (PhD)}

Associate professor

Eszterházy Károly University

Institute of Rural Development and Landscape Management demeter.dora@nak.hu 